\title{
The forever kitten
}

\author{
Beyond nine lives.
}

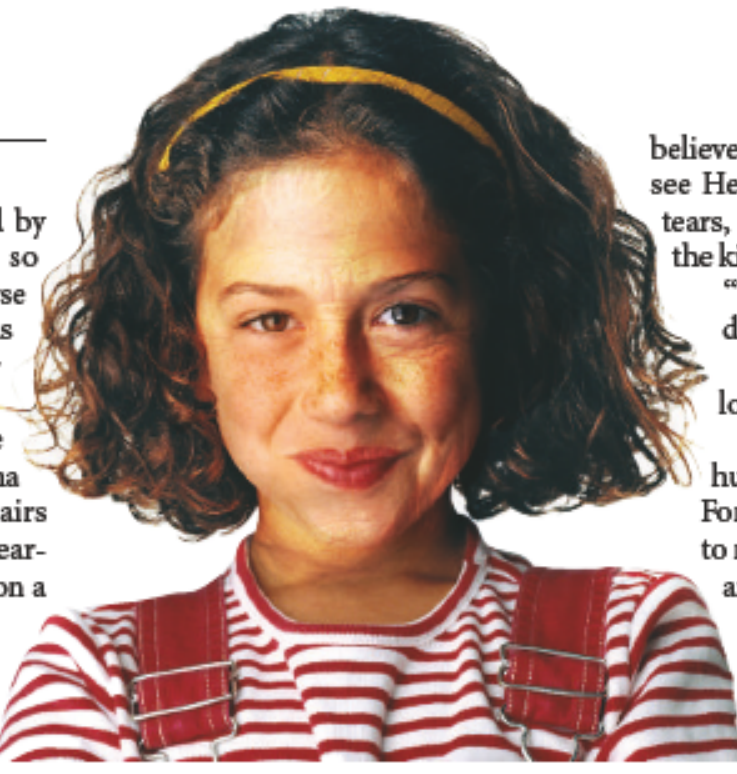

that human rejuvenation is possible.

I recognized the greed in his eyes: it wasn't pleasant. "It's still a long way off. This procedure was just the first of a great many. It has no real practical application, we can't use it on an adult. Once a mammal reaches sexual maturity its cells can't accept such a radical modification."

"We have every confidence that in the end you'll produce the result we all want."

I turned back to the child with her pet, feeling more optimistic than I had in three years. "I can do it," I said through clenched teeth. "I can." Revenge, it is said, is best served cold. I could see myself looking down on the gravestones of those fools in the Bioethics Commission in, say...oh, about 500 years' time. They'd be very cold indeed by then.

Joe's affable smile suddenly hardened. I turned, fearing the police had arrived. I'm still very twitchy about raids.

It wasn't the police. The teenage girl coming out from the house was dressed in a black leather micro-skirt and very tight scarlet T-shirt. She would have been attractive if it wasn't for the permanent expression of belligerence on her face; the tattoos weren't nice either. The short sleeves on the T-shirt revealed track marks on her arms. "Is that..."

"Saskia," Joe said with extreme distaste.

I really wouldn't have recognized his older daughter. Saskia used to be a lovely girl. This creature was the kind of horror story that belonged on the front page of a tabloid.

"Whatcha starin' at?" she demanded.

"Nothing," I promised quickly.

"I need money," she told her father.

"Get a job."

Her face screwed up in rage. I really believed she was going to hit him. I could see Heloise behind her on the verge of tears, arms curling protectively around the kitten.

"You know what I'll do to get it if you don't," Saskia said.

"Fine," Joe snapped. "We no longer care."

She made an obscene gesture and hurried back through the mansion. For a moment I thought Joe was going to run after her. I'd never seen him so angry. Instead he turned to his wife, who was frozen in her chair, shaking slightly. "Are you all right?" he asked tenderly.

She nodded bravely, her eyes slowly refocusing.

"What happened?" I asked.

"I don't know," Joe said bitterly. "We didn't spoil her, we were very careful about that. Then about a year ago she started hanging out with the wrong sort: we've been living in a nightmare ever since. She's quit school; she's got a drug habit, she steals from us constantly, I can't remember how many times she's been arrested for joyriding and shoplifting."

"I'm sorry. Kids, huh!"

"Teenagers, he said wretchedly. "Fiona needed two Prozac gland implants to cope."

I smiled over at Heloise, who had started playing with the kitten again. "At least you've got her."

"Yes." Joe seemed to make some kind of decision. "Before you leave, I'd like you to perform the cellular stasis-regeneration procedure for me."

"I don't understand. I explained before, it's simply the first stage of verifying the overwrite sequence we developed"

His attitude changed. "Nevertheless, you will do it again. Without my help you will be going back to prison for a long time."

"It's of no use to adults, "I said helplessly. "You won't become young, or even maintain your current age."

"It's not for me," he said.

"Then who..." I followed his gaze to Heloise. "Oh."

"She's perfect just the way she is," he said quietly. "And that, Doctor, is the way she's going to stay."

Peter F. Hamilton is the author of many

SF novels, including Pandora's Star, Fallen Dragon, Misspent Youth and the Night's Dawn trilogy, as well as the Greg Mandel mysteries. His latest, Judas Unchained, will be published in October. 